\title{
Coping with the Merger Guidelines and the government's "fix-it-first" approach: a modest appeal for more information
}

BY THOMAS M. JORDE*

\section{Introduction}

For almost 20 years the United States government has conducted its merger policy through the use of official Merger Guidelines. Merger Guidelines first appeared in 1968.' They were substan-

- Professor of Law, Boalt Hall School of Law, University of California, Berkeley.

AUTHOR'S NOTE: I thank Stephen Bundy, Richard Buxbaum, Robert Lande, Edward Rubin, and Lawrence Sullivan for their helpful comments. I especially thank Alan Fisher and Robert Harris for their insights and encouragement. An earlier version of this article was presented at the Sixtieth Annual Western Economic Association International Conference, Anaheim, California, July 1985, in a session organized by Fisher of the Federal Trade Commission, Washington, D.C.

I was invited to discuss this proposal in testimony before the Subcommittee on Monopolies and Commercial Law, Committee on the Judiciary, United States House of Representatives, in hearings on Merger Enforcement Policy and H.R. 586 (March 26, 1987).

1 United States Department of Justice Merger Guidelines (1968) [hereinafter cited as 1968 Guidelines], reprinted in 2 TRADE REG. REP. (CCH) I 4510.

c) 1987 by Federal Legal Publications, Inc. 
tially revised in $1982^{2}$ and fine tuned in $1984 .{ }^{3}$ Evolution of the guidelines shows a marked movement from simplified analysisbased on market structure-to complex, multifactor analysisbased on market structure, other market factors, financial trends, and efficiencies. Equally important, government enforcement has evolved from a prosecutorial approach, in which the courts played a significant role, to a more regulatory approach, in which the Department of Justice (DOJ) and Federal Trade Commission (FTC) employ a "fix-it-first" strategy of cutting deals to facilitate mergers. ${ }^{4}$

These changes have greatly increased the government's flexibility and discretion in merger enforcement. Indeed, they provide the government with the tools to conduct industrial policy on an industry-wide basis, without calling it that. Overall, these may be positive developments in merger analysis and policy, but they have come at a cost to the business community and the public of less predictability and stability in the law concerning mergers. A "reasoning gap" has been created that can and should be remedied.

In this article, I suggest a reporting requirement that will help restore predictability to merger analysis by increasing the flow of significant information from the government enforcement agencies concerning how the Merger Guidelines are actually interpreted and applied. Before describing this information-reporting

2 United States Department of Justice Merger Guidelines (1982) [hereinafter cited as 1982 Guidelines], reprinted in 2 TRADE REg. ReP. (CCH) II 4500-4505.

3 United States Department of Justice Merger Guidelines (1984) [hereinafter cited as 1984 Guidelines], reprinted in ANTITRUST \& TRADE REG. Rep. (BNA) No. 1169 (Special Supp. June 14, 1984); 49 Federal Reg. 26,823 (June 29, 1984).

4 Indeed, Charles F. Rule, Deputy Assistant Attorney General at the Justice Department's Antitrust Division, is reported to have said: "Unlike any past administration, we've developed a fix-it-first doctrine for antitrust policy. Why stop an entire merger if simply one-tenth of the assets create an anticompetitive problem?" N.Y. Times, Sept. 16, 1986, at 34 . 
approach, I first discuss the goals and evolution of the Merger Guidelines.

\section{Goals of Merger Guidelines}

The primary purpose of guidelines, of course, is to guide. When the government issues Merger Guidelines to make antitrust enforcement more predictable, it hopes to influence the behavior of business executives, strategic planners, investment bankers, accountants, economists, lawyers, and others involved in planning and executing mergers. Public disclosure of enforcement policies and procedures is intended to enable those engaged in the merger process to assess risk and plan transactions better. ${ }^{5}$ In addition, to the extent that guidelines are rational and aid predictability, they also have the potential to influence and guide the courts - a prospect that the DOJ welcomes.

5 Both the Merger Guidelines of 1982 and of 1984 expressly provide that "by stating its policy as simply and clearly as possible, the DOJ helps to reduce the uncertainty associated with enforcement of the antitrust laws in this area." 1982 Guidelines, supra note $2, \S 1$; 1984 Guidelines, supra note $3, \S 1$.

6 Although the Merger Guidelines are not binding on courts, they have been given considerable weight in many cases. See, e.g., United States v. Waste Management, Inc., 793 F.2d 976, 982-83 (2d Cir. 1984); United States v. American Cyanamid Co., 719 F.2d 558, 566-67 (2d Cir. 1983); Freuhauf Corp. v. FTC, 603 F.2d 345, 353-54 (2d Cir. 1979); Stanley Works v. FTC, 469 F.2d 498, 504 n.13, 505 n.16 (2d Cir. 1972), cert. denied, 412 U.S. 928 (1973). See Monfort of Colorado, Inc. v. Cargill, 591 F. Supp. 683, 695-96 (D. Colo. 1983), aff'd, 761 F.2d 570 (10th Cir. 1985), reprinted in 48 Antitrust \& TRAdE REg. ReP. (BNA) 774-79 (May 2, 1985), for a recent case indicating that courts sometimes 1 . rely on standards developed in judicial precedents arising under section 7, rather than on the DOJ's Merger Guidelines. The potential influence of the Merger Guidelines in court proceedings is particularly important, because so little private litigation concerns merger enforcement. See Harris \& Jorde, Market Definition in the Merger Guidelines: Implications for Antitrust Enforcement, 71 CALIF. L. REv. 464 (1983).

7 See Schwarts, The New Merger Guidelines: Guide to Governmental Discretion and Private Counseling or Propaganda for Revision of the Antitrust Laws?, 71 CALIF. L. Rev. 575 (1983); Werden, Market 
Predictability, however, is not the only goal of Merger Guidelines. Flexibility also is important because it enables the government to be sensitive to unique facts of a particular merger or to an industry's changing conditions. Unfortunately, predictability and flexibility are conflicting goals. Predictability is maximized by guidelines that are clear, readily understood, and easily administered-i.e., specific, simple rules of thumb. Flexibility, on the other hand, is maximized by guidelines that are thorough and adaptable-i.e., open-ended, transaction-specific analysis. The Merger Guidelines of 1968, 1982, and 1984 each have courted predictability and flexibility but have made very different tradeoffs between the two.

\section{Evolution of the Merger Guidelines}

\section{A. 1955: multifactor analysis}

Although the government did not issue formal Merger Guidelines in 1955, an Attorney General's Report published that year ${ }^{8}$ commented on the Celler-Kefauver Amendments ${ }^{9}$ and recommended a multifactor, case-by-case approach to merger analysis. However, because the report listed more than 50 separate factors for merger analysis without assigning weight or priority, it did little to promote predictability in merger enforce-

Delineation and the Justice Department's Merger Guidelines, 1983 DukE L.J. 514. Werden, a senior economist at the Antitrust Division of the DOJ, writes: "Judges should find life much easier and probably will produce significantly better decisions if they adopt the conceptual framework of the Guidelines. Rather than determining which opposing expert has the more sensible approach, judges could more easily evaluate the critical factual issues if all the experts were forced to discuss the problem under a common set of principles such as those in the Guidelines. With luck the courts will also see it this way."

8 Report of the Attorney General's National Commission to Study the Antitrust Laws (1955) [hereinafter cited as 1955 Report].

9 Celler-Kefauver Amendments to Clayton Act, S. Rep. No. 1775, 81st Cong., 2d Sess. 4-5 (1950). 
ment. In a forceful critique, then-Professor Bok advocated that "a dizzying list of factors" be replaced by a simplified, presumptive approach based on market structure. ${ }^{10}$ In United States v. Philadelphia National Bank," the Supreme Court adopted this basic structural approach. ${ }^{12}$

\section{B. 1968: market structure analysis}

The 1968 Merger Guidelines greatly enhanced predictability in merger analysis. Following Bok's advice and the lead of the Supreme Court, ${ }^{13}$ the DOJ focused centrally on market structure and emphasized market structure promised to be far more administrable-and therefore more predictable - than the multifactor approach of the 1955 Report. ${ }^{\text {It }}$ Moreover, this new ap-

10 M. Blecher, Bright Lines v. Case-by-Case Assessment in Antitrust Analysis-The Private Plaintiff's Point of View (unpublished manuscript).

11374 U.S. 321 (1963).

12 The Court adopted a burden-shifting approach based on market structure. A plaintiff could establish a prima facie case of illegality based on market shares and increases in market concentration, and it was the defendant's burden to refute this presumption. See Harris \& Jorde, Antitrust Market Definition: An Integrated Approach, 72 CALIF. L. Rev. 1 (1984).

13 Brown Shoe Co. v. United States, 370 U.S. 294 (1962), essentially adopted the 1955 approach. However, the Court changed its mind soon after in United States v. Philadelphia Nat'l Bank, 374 U.S. 321 (1963), and adopted a structural approach. But, in United States v. Von's Grocery Co., 384 U.S. 70 (1966), and United States v. Pabst Brewing Co., 384 U.S. 586 (1966), the Court pushed structural analysis to its zenith. In these cases, the Court found that postmerger market shares of 7.75 percent and 4.49 percent, respectively, violated the Clayton Act. The 1968 Merger Guidelines, however, did not go to these extremes.

14 Of course, just because the 1968 Merger Guidelines improved on earlier multifactor analysis does not mean that they were free from fault. For example, because the market definition provisions of $\S 3$ were vague, they were not particularly helpful in increasing predictability. 1968 Guidelines, supra note 1. 
proach closely followed prevailing economic theory concerning market concentration and market power. ${ }^{\text {1s }}$

While structural analysis promised increased predictability, it also was subject to manipulation and abuse through wooden market definition or talismanic use of market shares criteria. Six years after the guidelines were issued, the Court moved to check the potential excesses of a simplified structural approach by opening the analysis to include a qualitative, dynamic assessment of a firm's market share and market power. ${ }^{16}$

\section{1982: market structure plus other market factors analysis}

The 1982 Merger Guidelines brought the DOJ in line with judicial developments and changes in economic theory. ${ }^{17}$ The guidelines continued to employ market structure analysis, but they also included analysis of other market factors to gauge market power and determine whether a merger might substantially lessen competition.

Although the guidelines retained a structural approach, they substantially revised the method for defining markets and for calculating market shares. ${ }^{18}$ The 1982 Guidelines employed a "provisional" market approach to define relevant product and geographic markets. They did so by referring to demand and supply responses to a hypothetical future price increase of 5

15 Pautler, A Review of the Economic Basis for Broad-Based Horizontal-Merger Policy, 28 Antitrust Bull. 571 (1983).

16 See United States v. General Dynamics Corp., 415 U.S. 486 (1974); United States v. Marine Bancorporation, 418 U.S. 602 (1974); United States v. Citizens and Southern Nat'l Bank, 422 U.S. 86 (1975).

17 See Pautler, supra note 15. For a thorough review and assessment, see 1982 Merger Guidelines, 71 Calif. L. Rev. 280 (1983).

18 See Harris \& Jorde, supra note 6, for a critique. Harris and Jorde describe and advocate a dynamic approach to market definition in Harris \& Jorde, supra note 12 . Their approach and other methods of market definition are thoroughly discussed in ABA MONOGRAPH No. 12, Horizontal Mergers: Law and Policy (1986). 
percent. After defining the-relevant market, the guidelines used the Herfindahl-Hirschman index $(\mathrm{HHI}),{ }^{19}$ rather than market shares and four-firm concentration ratios, to measure increases in market concentration and threshold levels of concentration that would trigger potential enforcement.

The guidelines used structural analysis alone to support nonintervention in mergers in industries having postmerger HHIs below 1000. However, other market factors were expressly considered in the analysis of mergers in industries having postmerger HHIs between 1000 and 1800 and when the merger would increase the $\mathrm{HHI}$ by 100 or more. Other factors also were considered when the postmerger HHI was 1800 or above and the merger would increase the HHI by at least 50 . These "other market factors" included ease of entry, product homogeneity, quality of the next-best product substitutes, availability of market information concerning firm-specific transactions, buyer characteristics, past market conduct of the merging firms, and overall market performance. Any of these factors might prompt the government to modify its initial assessment of market power.

The 1982 Guidelines greatly expanded the number of market factors the government would analyze, but an "efficiencies" defense was specifically rejected except in "extraordinary" cases..$^{20}$ Although it recognized that trade-off analysis between market power and efficiencies is theoretically possible, the DOJ was un-

19 The Herfindahl-Hirschman index is defined as the sum of the squares of the market shares of all firms in the relevant market. If these shares are expressed as two-digit percentages, the outcome of the calculation is to be compared to the relevant guideline. For example, in a market consisting of eight equal-sized firms, each would have a share of 12.5 percent and the $\mathrm{HHI}$ would be $1250\left(8 \times(12.5)^{2}\right)$. According to the 1984 Guidelines, a merger between two of these firms would receive close scrutiny from the DOJ because it would increase the $\mathrm{HHI}$ to $1562.5\left(6 \times(12.5)^{2}+(25)^{\circ}\right)$, a rise of more than the DOJ's standard of 100 points in such a case. See 49 Fed. Reg. 26,823, 26,831 (1984).

20 The guidelines state: "At a minimum, the Department will require clear and convincing evidence that the merger will produce substantial cost savings resulting from the realization of scale economies, 
willing to undertake such analysis because claimed efficiencies are easier to allege than to prove and measure. ${ }^{21}$ This position had a great deal of merit in light of the expansive market definition approach and relatively high threshold HHI levels already incorporated in the guidelines. ${ }^{22}$

\section{1984: market structure plus other market factors plus financial trends plus efficiencies}

The 1984 Merger Guidelines adhere to the approach of the 1982 Merger Guidelines, which focused on basic market structure plus other factors. However, the 1984 Guidelines add important clarifications and significant new factors to the analysis. The clarifications concern the market definition process and the treatment of foreign competition. ${ }^{23}$ The new guidelines make

integration of production facilities, or multiplant operations which are already employed by one or more firms in the industry and that the equivalent results could not be achieved within a comparable period of time through internal expansion or through a merger that threatened less competitive harm. In any event, the Department will consider such efficiencies only in resolving otherwise close cases." 1982 Guidelines, supra note $2, \S \mathrm{V}(\mathrm{A}) \&$ n. 53 .

In its separate statement concerning the guidelines, the FTC indicated that it would consider efficiencies on a case-by-case basis. The FTC also indicated that it would focus on measurable operating efficiencies, such as production or plant economies of scale. See FTC Statement Concerning Horizontal Mergers, June 14, 1982, reprinted in Trade Reg. Rep. (CCH) No. 546, at 73 (June 16, 1982) (Special Supp. to 2 Trade Reg. Rep. \4225 (Aug. 9, 1982)) [hereinafter cited as FTC Statement].

$21 \quad 1982$ Guidelines, supra note $2, \S \mathrm{V}(\mathrm{A})$.

22 See, e.g., Harris \& Jorde, supra note 6, at 479-81; Fisher \& Lande, Efficiency Considerations in Merger Enforcement, 71 CALIF. L. Rev. 1580 (1983); Kauper, The 1982 Horizontal Merger Guidelines: Of Collusion, Efficiency, and Failure, 71 CALIF. L. Rev. 507, 521 (1983).

23 The 1982 Merger Guidelines' weaknesses concerning market definition and foreign competition were noted and discussed in Harris \& Jorde, supra note 6 . The 1984 Merger Guidelines appear to have responded to these criticisms and to the proposed adjustments. 
clear that the DOJ normally will base market definition on historic market definition and will not rigidly apply the 5 percent test. ${ }^{24}$ Foreign competition is specifically addressed and handled in a rational manner. In determining the significance of a foreign firm's share of the domestic market, the guidelines take account of actual trade flows and government trade restrictions. ${ }^{25}$

The additions, however, are more significant. The new guidelines indicate an increased solicitude for the financial difficulties of merging firms and for financial trends in the industry. Although the classic "failing company" defense is retained, ${ }^{26}$ a "failing division" defense is now separately specified. ${ }^{27}$ In addition, the guidelines add "financial difficulties of a firm" to the

24 The "5 percent test" refers to the standard by which the guidelines define the product market relevant to a merger. In applying it, "[T]he Department will begin with each product (narrowly defined) produced or sold by each merging firm and ask what would happen if a hypothetical monopolist of that product imposed a 'small but significant and nontransitory' increase in price. If the price increase would cause so many buyers to shift to other products that a hypothetical monopolist would not find it profitable to impose such an increase in price, then the Department will add to the product group the product that is the nextbase substitute for the merging firm's product and ask the same question again. This process will continue until a group of products is identified for which a hypothetical monopolist could profitably impose a 'small but significant and nontransitory' increase in price. The Department generally will consider the relevant product market to be the smallest group of products that satisfies this test. . . .

"In attempting to determine objectively the effect of a 'small but significant and nontransitory' increase in price, the Department in most contexts will use a price increase of five percent lasting one year. However, what constitutes a 'small but significant and nontransitory' increase in price will depend on the nature of the industry, and the Department at times may use a price increase that is larger or smaller than five percent." 1984 Guidelines, supra note 3, § 2.11 (notes omitted).

$25 I d . \S \S 2.34,3.23$.

26 See id. $\$ 5.1$.

27 Id. $\S 5.2$. Section V(B) n.57 of the 1982 Guidelines, supra note 2 , mentioned that this defense was possible, but did not seem as openly inviting as do the 1984 Merger Guidelines. 
list of factors that might offset or diminish inferences of market power based on the structural analysis.

Expressly adding "efficiencies" to merger analysis, the 1984 Merger Guidelines indicate that efficiency gains may offset market power inferences drawn from structural analysis. The guidelines now state that regardless of the amount of increased market concentration brought about by a merger, the DOJ may decide not to challenge an otherwise troublesome merger if the parties are able to establish by "clear and convincing" evidence that the merger will produce significant net efficiencies. ${ }^{28}$ Merging parties may argue any efficiencies, including economies of scale, better integration of production facilities, plant specialization, and lower transportation costs. Even efficiencies resulting from reductions in general selling, administrative, and overhead expenses may be considered. ${ }^{29}$

\section{Assessing the changes-a return to multifactor analysis}

\section{A. Gains in flexibility}

The 1984 Merger Guidelines endow the government with extraordinarily broad discretion. All of the 1982 Merger Guidelines' flexibility is retained and then expanded by the addition

28 For a critique of the "clear and convincing" evidence standard, see Fisher \& Lande, supra note 22, at 1654, 1667. These authors note that such a standard may be an impossible evidentiary burden and, in any case, will substantially increase litigation costs.

29 The guidelines recognize that it may be difficult to demonstrate efficiencies not related to specific manufacturing, servicing, or distribution operations of the merging firms. 1984 Guidelines, supra note 3, $\S 3.5$. The FTC also considers efficiencies. FTC Statement, supra note 20; In re American Medical Int'l, Inc., Doc. 9158 (July 2, 1984) (Calvani, Comm'r). But the FTC's approach apparently is narrower than that of the guidelines because of "spreading of overhead" economies. Rather, the FTC's approach references efficiencies to long-run cost curves to ensure that only true scale effects are counted. R. Stoner, Merger Enforcement at the FTC Under the New Merger Guidelines 3133 (July 2, 1985) (paper presented at the Western Economic Association 
of other market factors and by a separate efficiencies analysis. Thus, after 30 years, the government appears to have come full circle and has returned to full-blown multifactor merger analysis. To be sure, market structure elements of modern merger analysis provide a useful screening tool for swift approval of the vast majority of mergers-a tool that was not part of the 1955 Attorney General's Report. But for mergers that raise significant market power concerns, the multifactor approach has been reincarnated. This signals that lawyers and economists in government enforcement agencies intend to engage in sophisticated economic analysis sensitive to the particular facts of each merger transaction..$^{30}$ Of course, case-by-case, multifactor analysis also ensures that lawyers and economists representing merging parties can now advance virtually unlimited arguments regarding the unreliability of presumptive market structure data or the existence of net efficiencies.

\section{B. Losses in predictability}

Unfortunately, gains in flexibility from multifactor analysis tend to be offset by losses in predictability. The 1984 Merger Guidelines reduce predictability in two ways: first, the terms themselves substantially increase uncertainty and therefore di-

International Conference). For a general discussion of the DOJ's views concerning efficiencies, see Warren-Boulton, Merger Policy and Enforcement at the Antitrust Division: The Economist's View, 54 ANTITRUST L.J. 109-115 (1985). If the DOJ and the FTC are indeed treating spreading-of-overhead efficiencies differently, an intolerable situation exists that should be resolved by the two enforcement agencies. Otherwise, different outcomes in merger analysis may occur, depending on which agency happens to handle the transaction. This is particularly troublesome because case allocation between the agencies is based only upon the fact that one agency has already handled cases in the industry in question. See infra note 39.

30 Some would argue that the intended sophistication is either illusory or impossible, in light of the data limitations and the time constraints in merger analysis. See Areeda, Justice's Merger Guidelines: The General Theory, 71 Calif. L. Rev. 303, 308-10 (1983); Fisher \& Lande, supra note 22, at 1624-77. 
minish the usefulness of the guidelines as a predictive tool for business planning. Second, the manner in which the guidelines are actually applied has increased uncertainty.

1. Regarding the terms of the guidelines, a number of problem areas emerge:

a) The market definition process promises to increase uncertainty because it focuses upon hypothetical price increases by a hypothetical monopolist and the anticipated supply and demand responses thereto. ${ }^{31}$ Uncertainty is compounded because the guidelines fail to place the new approach to market definition into the context of the more traditional methods used by the courts. Thus little "common law" exists to indicate how elements of the new approach might be applied to particular firms and industries. ${ }^{32}$

b) When the government evaluates a merger that increases market concentration above threshold HHI levels, the long list of factors considered is essentially open-ended and unweighted. No guidance exists to indicate the relative importance of particular factors, to indicate when a factor might offset or diminish market structure inferences of market power, or to indicate how various factors might combine to save a merger.

c) The guidelines' focus upon the financial condition of merging firms and on financial trends in the industry (whether as part of market power analysis or as a failing company or failing division defense) reduces predictability in the merger analysis process. As with other factors, little guidance is given concerning what constitutes financial difficulties, how these difficulties are to be measured, and what order of magnitude is sufficient to offset structural inferences of market power.

31 See, e.g., Areeda, supra note 30, at 308; Harris \& Jorde, supra note 6 , at $481-84$.

32 Indeed, when the DOJ attempted to utilize the new approach in merger litigation, the court found the approach too speculative to be useful and instead employed more traditional analysis. United States v. Virginia Nat'l Bankshares (W.D. Va. 1982) (oral bench opinion), reported in 2 Trade Cas. (CCH) I 64,871, discussed in Harris \& Jorde, supra note 6 , at 488 . 
d) Adding analysis of efficiencies as a possible offset to market power promises to complicate merger analysis and to increase uncertainty. ${ }^{33}$ The addition of efficiencies may constitute a form of "double counting," if the expansive market definition approach and relatively high $\mathrm{HHI}$ threshold numbers adopted in the 1982 Merger Guidelines already capture the vast majority of demonstrable efficiencies. Beyond that, the guideline provisions concerning efficiencies invite exceedingly open-ended argument and analysis. Any type of efficiency can be claimed..$^{34}$ The list of examples appears to focus only on static efficiencies. But in light of the broad language-and certainly the spirit-of the guidelines, the merging parties can also advance dynamic efficiencies. However, such efficiencies must be more difficult to prove and measure. ${ }^{35}$ Whether the efficiencies are static or dynamic, the guidelines also fail to indicate whether certain types are considered more important than others, whether diseconomies will also be part of the calculus, or what magnitudes of savings are significant enough to offset prima facie evidence of market power. ${ }^{36}$

33 See Fisher \& Lande, supra note 22, for an excellent critique.

34 See supra note 29 and accompanying text.

35 See Fisher \& Lande, supra note 22, at 1634-36. Arguments concerning quality enhancement were made by the merging parties in American Medical, supra note 29. In an article in this issue, Fisher, Johnson, and Lande analyze the difficulties of including such factors in the tradeoff between efficiency and market power. Fisher, Johnson \& Lande, Do the DOJ Vertical Restraints Guidelines Provide Guidance?, 32 ANTITRUST BULL. 609 (1987).

36 These questions seem particularly pertinent in view of the 1982 Merger Guidelines' skepticism concerning efficiency claims. The guidelines, supra note 2, stated in $\$ \mathrm{~V}(\mathrm{~A})$ : "Plausible efficiencies are far easier to allege than to prove. Moreover, even if the existence of efficiencies were clear, their magnitudes would be extremely difficult to determine." For an inside view of how the FTC treats efficiency claims, see R. Stoner, supra note 29, at 31-33; for the DOJ, see Warren-Boulton, supra note 29. 
2. The second source of erosion to predictability stems from the manner in which the guidelines have been applied by the current administration:

a) The fact that the 1982 Merger Guidelines were revised after only two years, while the same Administration was in power, signals that the guidelines may be revised frequently. It plainly increases the likelihood that a new Administration will not hesitate to change the guidelines. Such frequent revision, of course, deprives merger analysis of continuity and makes business planning difficult, particularly if substantial changes are involved.

b) The government appears to take a regulatory approach to merger enforcement under the guidelines. The Hart-ScottRodino (HSR) $\mathrm{Act}^{37}$ requires that before mergers of significant size are consummated, they be reported to the DOJ and the FTC. ${ }^{38}$ This requirement is to facilitate a review of potential antitrust problems. ${ }^{39}$ If the initial filing indicates that the merger may be anticompetitive, a "second request" for additional and more detailed information may be made. Of approximately 1,000 annual HSR filings, a second request is made in only about 5 to 8 percent of the cases. ${ }^{40}$ Additional review of these cases usually

37 Hart-Scott-Rodino Act, 15 U.S.C. § 18a (1976).

38 The guidelines have been promulgated by the DOJ. However, the FTC's enforcement policies closely parallel those of the DOJ. Indeed, the FTC has indicated that it will give "considerable weight" to the DOJ's guidelines in its decisions. See FTC Statement, supra note 20.

39 Premerger notification filings are submitted to both the DOJ and the FTC. The two governmental agencies have established an informal manner of allocating cases on the basis of which agency is best able to conduct an investigation. This usually depends on agency expertise in a particular industry. Andewelt, Merger Policy and Enforcement at the Division: The Lawyer's View, 54 AnTITRuST L.J. 95, 95-101 (1985).

40 Annual statistics are reported in the FTC's Annual Hart-ScottRodino Reports, filed as required by $\S 18 \mathrm{a}(\mathrm{j})$ of the act. In 1984 , second requests were issued in 77 cases. Of that number, the DOJ was responsible for 40 , which resulted in 5 complaints being filed. In 1983, 48 second 
results in a "no-action" decision or in a "fix-it-first" consent settlement reached before a complaint is filed. Only rarely has the current Administration actually prosecuted a merger by filing a complaint and seeking an injunction.

Because of these no-action decisions and fix-it-first consents, the public at large-and the business community specifically-has little information as to how the guidelines are interpreted and applied. When the government takes no action or arranges a partial divestiture by consent, it usually does not explain its reasoning. Rather, it typically issues a short announcement stating that the acquisition did not raise sufficient competitive concerns to warrant an antitrust suit. ${ }^{41}$ Only when a merger is large enough to catch the public's attention is there greater disclosure. ${ }^{42}$ Therefore, in most cases, including those in which a second request has been made, it is not possible to ascertain why a

requests were made. The DOJ was responsible for 28 , which resulted in 2 merger transactions being voluntarily withdrawn, 38 no-action decisions, 5 fix-it-first restructurings, and 3 complaints filed. (This information was provided by the DOJ's Office of Operations.)

41 See, e.g., 48 Antitrust \& Trade Reg. Rer. (BNA) 395 (Feb. 28, 1985): "The Antitrust Division announced this week that it will not challenge Minebea Co. Ltd's proposed acquisition of New Hampshire Ball Bearing Inc. New Hampshire Ball Bearing is based in Peterborough, N.H., and Minebea is located in Tokyo. On Feb. 26, Assistant Attorney General J. Paul McGrath explained that after an extensive investigation, the Division concluded that the acquisition did not raise sufficient competitive concerns to warrant an antitrust enforcement suit."

42 The recent LTV-Republic merger is an excellent example. Initially, the DOJ announced its opposition to the proposed merger between the nation's third and fourth largest steel producers. The announcement detailed concern over increases in market concentration and the apparent lack of significant expected economies. See 46 ANTItrust \& Trade Reg. Rep. (BNA) 270-71 (Feb. 16, 1984). The DOJ's position stirred controversy within the Administration, and eventually the DOJ cleared the merger on the condition that LTV sell off two Republic Steel mills. The government agency explained that the proposed restructuring would alleviate concentration problems. Other factors which were said to have weighed in favor of the merger approval included ease of entry, homogeneity of the product, and anticipated efficiencies. See 46 ANTItrust \& Trade Reg. Rep. (BNA) 502-04 (Mar. 15, 1984); 46 ANTItrust \& Trade Reg. Rer. (BNA) 577-78 (Mar. 22, 1984). 
merger was permitted. The relevant market may have been defined in a manner that left the merging firms with small market shares; the market shares may have been sufficiently high to infer market power, but other market factors were interpreted as having reduced the potential anticompetitive threat of the merger; the poor financial condition of the firms may have been thought to reduce the potential anticompetitive threat of the merger; or net efficiency gains from the merger may have been found to offset market power.

The government's regulatory approach thus retards the development of a "common law" regarding the meaning of the guidelines and thereby contributes to a general lack of predictability. Furthermore, the public's lack of information regarding interpretation and application of the guidelines fosters "privatization" of information in specialized law firms, usually in Washington, D.C., and New York. These firms develop their own information sources through a high-volume merger practice that puts them in regular contact with government enforcement officials. Leaks or inside contacts yield information to these firms.

If government enforcement officials limited their activities primarily to prosecuting cases and relied on the courts to determine the boundaries of substantive merger law, more of the government's reasoning regarding the guidelines would become available to the public. Such information would be revealed either through settlements reached on complaints filed under the Tunney $\mathrm{Act}^{43}$ or through court opinions, which typically detail the

43 Sections 16(b)-(h) of the Tunney Act (1982) require that the DOJ file a competitive impact statement when it proposes to settle an antitrust suit after a complaint has been filed. The DOJ is required to set forth the nature of the proceedings and to explain how the consent judgment remedies the perceived antitrust concerns. The public is given an opportunity to comment, and the federal district court must find that the proposed settlement is in the public interest. $C f$. Buxbaum, Public Participation in the Enforcement of the Antitrust Laws, 59 CALIF. L. REv. 1113, 1114 (1971). 
government's theories and evidence. ${ }^{44}$ Moreover, the "reasoning gap" concerning how the guidelines are interpreted will not be filled through private merger enforcement. Private parties have too little opportunity or financial incentive to challenge prospective mergers. ${ }^{45}$ Besides, such litigation and court opinions still would not provide information concerning the government's views.

The lack of good information concerning the government's interpretation of the guidelines is particularly significant when the various factors of analysis themselves are often unclear and unexplained, as in the case of the 1984 Merger Guidelines. Report of a recent no-action decision concerning a merger in the titanium dioxide industry illustrates the type of information concerning interpretation and application of the guidelines that is important for business-planning purposes. However, such information typically is not available to the public because a complaint is not filed and prosecuted..$^{46}$

The FTC declined to challenge a major acquisition in the titanium dioxide industry, in which SMC Corp. sought to purchase two manufacturing facilities owned by Gulf + Western Industries, Inc. "Informal sources" reported to the Bureau of

44 Most trial or appellate court opinions that discuss merger transactions demonstrate the thoroughness with which facts and theories are discussed. For recent examples that also discuss the 1984 Merger Guidelines, see United States v. Waste Management, Inc., 793 F.2d 976, 98283 (2d Cir. 1984), and White Consolidated Indus. v. Whirlpool Corp., No. C85-472 (E.D. Ohio, July 3, 1985), reprinted in 49 ANTITRUST \& Trade Reg. Rer. (BNA) 91 (July 11, 1985).

45 See Areeda, supra note 30, at 305; Harris \& Jorde, supra note 6, at 491 . Of course, some private merger litigation does occur. See, e.g., Monfort, supra note 6; Chrysler v. General Motors, 589 F. Supp. 1182 (D.D.C. 1984); White Consolidated Indus., supra note 44. Furthermore, reduced government enforcement may lead to greater private enforcement. See M. Blecher, supra note 10.

46 The account of SMC's acquisition of Gulf + Western facilities is drawn from the report of the Bureau of National Affairs' 45 ANTITRUST \& TRADE Reg. Rer. 751 (Nov. 11, 1983). 
National Affairs that a complaint was not issued because the concentration figures were below $\mathrm{HHI}$ thresholds in the guidelines. Had the market been defined as domestic, including actual foreign imports, $\mathrm{HHI}$ market concentration figures would have placed the industry in the "highly concentrated" category. In that case, the combined market shares of SMC and Gulf + Western would have increased market concentration by more than 100 points, which would have made the acquisition "likely" to be challenged under the guidelines. However, the FTC decided that all of Europe's production capacity should be included in the market. ${ }^{47}$

The wisdom of this decision is certainly open to question..$^{48}$ However, the important point here is that the FTC apparently adopted a very expansive approach to market definition. If the reported information is correct, the FTC's reasoning and approach to the market definition process obviously are important to those planning future acquisitions in the titanium dioxide industry or in other industries sharing similar characteristics. Unfortunately, this information had to be generated from informal sources inside the FTC.

\section{Costs of reduced predictability}

A multifactor approach to merger analysis reduces the predictability that might be expected from guidelines. This is especially true when the guidelines lack both internal clarity and external clarification. Several significant costs result. ${ }^{49}$

47 See id. The BNA report also indicates that the commissioners sharply disputed the relevant geographic market and alleged efficiencies. Commissioners Pertschuk and Bailey voted to seek an injunction.

48 Compare Harris \& Jorde, supra note 12, at 62-64, with Landes \& Posner, Market Power in Antitrust Cases, 94 Harv. L. Rev. 937, 963-66 (1981).

49 For general analyses of the costs of imprecise, open-ended rules, see Ehrlich \& Posner, An Economic Analysis of Legal Rulemaking, 3 J. 
From the perspective of an individual merger transaction, the complexity and uncertainty in the 1984 Merger Guidelines are likely to raise costs of filings and investigations prior to mergers, and of any subsequent litigation. Certainly, parties can be expected to take advantage of the invitation to thoroughness inherent in a multifactor approach. Probably the most dramatic cost increases are associated with the new efficiencies analysis in the guidelines, as the parties and the government attempt to explore and define its boundaries. ${ }^{50}$

From a broader business-community perspective, a loss of predictability in the guidelines means that companies interested in acquisitions face increased investigation and justification costs. Estimating the extent of such costs is difficult. Therefore, to assess antitrust risks properly, potential merging parties and their advisers must spend more time and money trying to understand, weigh, and balance the multiple factors that the government now considers in evaluating proposed mergers."

From an institutional perspective, the loss of predictability in the guidelines and the concomitant increase in government enforcement agencies' flexibility and discretion could give rise to a perception-if not reality-of ad hoc, unprincipled decision making. This, in turn, might lead to eroding confidence in the agencies.

Legal Stud. 257 (1974); Fisher \& Lande, supra note 22. Several commentators have noted the difficulties of measuring efficiencies and then conducting market power trade-off analysis. See, e.g., R. POSNER, ANTItrust Law (1976); R. Bork, The Antitrust Paradox (1978); Fisher \& Lande, supra note 22; Kauper, supra note 22, at 519-25. Fisher \& Lande conclude that the high costs of a case-by-case efficiencies defense, and the inherent imprecision of such analysis, strongly support eliminating an efficiencies defense. They suggest instead that efficiency concerns be incorporated by upwardly adjusting the guidelines' threshold for challenging mergers.

50 For a confirmation of the increased emphasis on efficiency claims, see R. Stoner, supra note 29, at 31-33.

51 For estimates of litigation cost implications, see Fisher \& Lande, supra note 22 , at $1673-76$ \& n.308. 
Finally, the government's fix-it-first policy toward mergers may be tantamount to an industrial policy for whole industries. If so, the public deserves to know the parameters and goals of such policies.

\section{Restoring predictability to the guidelines}

In my judgment, the multifactor analysis of the 1984 Merger Guidelines, combined with the current regulatory approach to merger enforcement, moves too far in the direction of flexibility and therefore causes an unnecessary loss of predictability. It is understandable - even commendable - that government lawyers and economists enforcing the merger laws desire to conduct a sophisticated analysis. But as part of that effort, reasonable steps should be taken to restore a greater level of predictability in the guidelines, and thus to reduce the costs of uncertainty.

Of course, it might be tempting to argue that the costs of reduced predictability are not really worrisome since the current Administration is so pro-business oriented. But multifactor analysis is not necessarily a ratchet. Regardless of whether an Administration is pro-business, the costs of complex multifactor analysis that detract from predictability are real. Therefore, these costs should be evaluated separately from a particular Administration's merger-approval track record.

A new Administration could easily employ multifactor analysis quite differently to produce results that would not seem nearly so pro-business. For example, the guidelines now proclaim that government enforcement agencies are capable of measuring efficiencies and of conducting market power trade-off analysis. Consequently, a new Administration could decide to err on the side of halting incipient market power gains. To do so, the new Administration could greatly lower the safe-harbor HHI threshold number and then require that parties proposing any merger above the new threshold demonstrate the merger's anticipated efficiency gains. Such an Administration could easily find virtually all such demonstrations unconvincing. 
Moreover, even when an Administration uses multifactor analysis in a manner that seems to favor mergers, ultimately a line must be drawn delimiting legal and illegal mergers. The business community must know where that line is so that ambiguous merger standards do not deter risk-averse firms from attempting socially beneficial mergers.

\section{A. A modest suggestion: increase the flow of information}

One way to increase predictability without greatly reducing the benefits of flexibility is to have the government enforcement agencies explain their no-action and fix-it-first merger decisions to the public. This information exchange could be accomplished by replacing the present system of ad hoc press releases and speeches or of occasional articles ${ }^{52}$ with a requirement that the government systematically and regularly report the reasons for its decisions. ${ }^{53}$ However, the vast majority of proposed mergers do not raise substantial competition problems. Therefore, the reporting requirement could apply only to those mergers for which the government issues a second request for additional information-a universe of only 50 to 80 mergers per year. ${ }^{54}$ Disclosure of the government's view would provide the public with valuable insights into how the government determines the relevant market as well as initial and postmerger HHI calculations. The public also would learn the importance of other mar-

52 E.g., Andewelt, supra note 39; McCarty, Merger Policy and Enforcement at the Federal Trade Commission: The Lawyer's View, 54 ANTITRUSr L.J. 103 (1985); Scheffman, Merger Policy and Enforcement at the Federal Trade Commission: The Economist's View, 54 ANTITRUST L.J. 117 (1985); R. Stoner, supra note 29; Warren-Boulton, supra note 29; White, Antitrust and Video Markets: The Merger of Showtime and The Movie Channel as a Case Study, in Competition Among New Video MEDia (ELI ed. 1985).

53 At the FTC, the reports could be prepared by the Bureau of Competition or the Bureau of Economics.

$54 \quad$ See supra note 20. 
ket factors, efficiencies, and/or defenses in the government's decisions.

Issuing a report after each merger decision would not be necessary. Rather, the benefits of increased information to the public could be achieved through quarterly reports, or perhaps as part of the annual reports now required by section $18 \mathrm{a}(\mathrm{j})$ of the HSR Act. ${ }^{35}$ The reports should contain information that is detailed enough to increase predictability in the guidelines, but not sufficiently transaction-specific to disclose any confidential business information provided by the merging parties.

\section{B. Benefits of a reporting requirement}

The most obvious benefit from increased information regarding the guidelines would be that the government's enforcement policies and practices would be better understood. Thus, the business community would be better able to evaluate and plan merger activity. As the government would report its reasoning over several cases, a "record" would begin to emerge that would help business executives and their advisers to assess risk and to predict more accurately the treatment of future merger transactions. For example, information that would become available would include whether the government viewed the relevant market for a particular product as worldwide, national, or regional; whether it hypothesized a 5 percent price increase or some other percentage for a particular product; how often it considered expected efficiencies to be significant enough to offset market power; which kinds of efficiencies it found demonstrable and what order of magnitude it considered necessary to offset market power; and which other market factors it deemed important in a particular industry.

Increased predictability in the guidelines should make it easier and therefore less costly for firms to identify viable merger candidates that will not raise antitrust concerns. If problems are identified, increased information regarding the government's

Id. 
views and past actions should help the merging parties to "fix" the merger, through partial divestiture or through some other means. Alternatively, merging parties may be in a better position to explain and defend a proposed merger with increased information concerning which efficiencies have been found persuasive, or under what circumstances a company's weakened financial condition has been found to offset structural inferences of market power. In short, reducing uncertainty by increasing the flow and volume of information to the marketplace should help the market for mergers to operate more efficiently.

Increasing the brightness of the line that separates legal and illegal mergers also is important for the national economy. Antitrust laws-particularly those governing mergers-are an integral part of U.S. industrial policy. These laws help shape the structure of American industry by indicating when government will intervene to prohibit business behavior or market structure changes that will harm competition. ${ }^{56}$ Ambiguity and uncertainty regarding the application of antitrust laws may cause excessive deterrence, as business tries to steer clear of possible antitrust liability. Such excessive deterrence can be costly to the extent that it discourages efficient or innovative behavior and market structure. Clear Merger Guidelines should help reduce deterrence of socially beneficial merger activity in the economy.

Finally, a reporting requirement would help ensure accountability and would enable the government to demonstrate its seri-

56 Antitrust laws may be thought of as archetypal general interest laws. See Easterbrook, Forward: The Court and the Economic System, 98 Harv. L. Rev. 4, 16-17 (1984). As such, bright lines that are clear and that give workable guidance to the business community are more appropriate than case-by-case analyses that determine the rights or obligations of individual parties. For that reason, it may be more appropriate to view antitrust rules differently from rules that apply to private conduct, such as contract law. Arguably, the latter should be more individualized, and thus more case-by-case oriented. See Eisenberg, The Responsive Model of Contract Law, 36 Stan. L. Rev. 1107 (1984). 
ousness and sophistication in merger analysis..$^{57}$ Moreover, it would give business, the public, the bar, and the academic community a sounder basis for evaluating the DOJ's policies and practices. ${ }^{58}$

\section{Evaluating possible objections}

Objections to any suggestion of change usually can be anticipated, even when the suggestion is as modest as a reporting requirement. Here, I address potential concerns.

First, there may be concern that a reporting requirement would be costly and burdensome. ${ }^{39}$ Of course, a reporting requirement could be expected to add to the government's cost of

57 As noted earlier (see supra note 28), several commentators have expressed grave doubts concerning the government's ability to measure efficiencies and to conduct trade-off analyses. A reporting requirement would give the government the opportunity to develop and demonstrate its skills and methods.

58 Professor Turner made this point even before the 1968 Guidelines were adopted: "One cannot decide rationally whether or not to recommend that a complaint be brought without having some idea, however tentative and crude, of what the appropriate rules of law should be. . . Moreover, to the extent that the enforcement agency, be it the DOJ or the FTC, has been able to come to a firm conclusion, there are many advantages to be gained and little to be lost from publicizing what that position is. People wishing to comply with what the Government thinks the law is can only do so if the Government's views are made known. Moreover, promulgation of the Government's views speeds up the processes of development of the law by laying the basis for a continuing dialogue among the Government, the bar, business groups and the academic profession. Publication of the Government's considered views will increasingly generate the kind of empirical data that will help us to decide whether tentative positions have gone too far or not far enough." D. Turner, Address before the Antitrust Section of the American Bar Association 6-7 (Aug. 10, 1965), cited in Joffe, Guidelines-Past, Present and Future, 50 ANTITRUst L.J. 187, 189 (1982).

59 For an argument that a reporting requirement may be too costly, see Langenfeld, The Impact of Antitrust Guidelines on Business, 4 CoNTEMPORary Policy Issues No. 3, at 22 (1986). 
merger enforcement, but the increase would likely be quite small. Government enforcement agencies already are making decisions under the Merger Guidelines. Although the guidelines' multifactor approach gives the agencies wide latitude, there is no reason to assume that their decisions are without standards. Government economists and lawyers, like the rest of us, are boundedly rational. For that reason, they probably have already developed and will continue to evolve internal benchmarks, priorities, and rough rules of thumb concerning how the guidelines should be interpreted and applied. The reporting requirement proposed here simply asks that this important information be disclosed for the relatively few cases for which the government makes a second request. The government's analysis concerning proposed mergers already is in written form in internal memoranda which could be summarized. Furthermore, costs could be kept down by employing a standardized reporting format. Such standardization also would facilitate comparisons across mergers and industries and would induce consistency in applying the guidelines. Finally, I believe that the additional costs of a reporting requirement would be more than offset by benefits from increased predictability.

Second, one may argue that a reporting requirement would interfere with the government's prosecutorial strategy. Of course, protecting prosecutorial strategy may be important in some contexts. For example, a local prosecutor's office may have a policy of not prosecuting theft cases unless a witness is available and willing to testify. In such cases, concern for witnesses and the potential loss of deterrence may justify not making such strategic information public. Similarly, it is easy to understand why the Internal Revenue Service does not announce which deductions it considers "red flags" that will trigger a tax audit.

Prosecuting mergers under the antitrust laws, however, is quite a different situation. Antitrust policy toward mergers plays an important role in shaping the nation's industrial structure. While prohibiting mergers that impede competition is important, facilitating and encouraging benign, efficient, or procompetitive mergers is equally important. Therefore, little 
justification exists for creating a penumbra of uncertainty surrounding enforcement standards to induce companies to stay well clear of the line of illegality. ${ }^{60}$ The economy is better served if businesses have a clear picture of merger standards and of how the government interprets and applies its guidelines.

A reporting requirement also would decrease the government's discretion in treating similar cases differently. But responsible authorities would not regard this effect as a loss. Like cases should be treated alike, and a reporting requirement, by creating an enforcement agency "common law," should encourage this result.

Third, concern may exist that a reporting requirement would cause disclosure of confidential business information provided by the merging parties. Responses to second requests routinely include business information concerning trade secrets or other confidential research, development, or commercial information. Preventing public disclosure of confidential information that might benefit competitors or otherwise harm the merging parties is important.

The reporting requirement suggested here would not necessitate disclosure of confidential information. Moreover, government enforcement agencies already understand the meaning and importance of confidential business information. When the DOJ litigates, it must comply with confidentiality requirements of Federal Rule of Civil Procedure 26(c)(7). It also must be sensitive to confidentiality concerns when it files Tunney Act competitive impact statements or renders opinions under its business review procedures. ${ }^{61}$ Similarly, the FTC already operates under internal rules that ensure the confidentiality of trade secrets and

60 To be sure, some firms that are willing to undergo the risks and expense may respond by challenging the line, which results in litigation costs. However, greater information concerning the government's enforcement standards should reduce even this "testing" litigation.

61 See 28 U.S.C. \&509; 28 C.F.R. ch. 1, § 50.6 (Judicial Administration, Department of Justice). 
competitively sensitive commercial or financial information. ${ }^{62}$ Finally, other governmental agencies, such as the Internal Revenue Service and the Securities and Exchange Commission, have issued interpretations of their rules and regulations or have explained why no action was taken in particular cases. ${ }^{63}$ Their experience suggests that antitrust enforcement agencies also should be able to protect confidential information and still provide the public with important information concerning merger enforcement under the guidelines.

Confidential responses to second requests could be summarized and aggregated in a manner that would not create confidentiality problems. Market structure information, including market definition and other market factors, generally could be reported without delving into sensitive information about the particular merging parties. Questions involving public information that could be addressed without disclosing confidential information include: Is the relevant market global, national, or even smaller; who are the relevant competitors and potential competitors; what is the industry HHI; and are barriers to entry high or low, and why? Specific market share calculations concerning the merging firms and changes in the HHI may involve firm-specific information, but should not be considered confidential.

A more serious confidentiality problem might arise with respect to reporting about expected efficiencies. The government typically receives this information directly from the merging parties, and the information usually includes confidential trade secrets, research and development plans, innovative methods of production and marketing, or other cost-saving ideas. The gov-

62 See 16 C.F.R. ch. 1 , $\$ 4.10$ (1985 ed.).

63 The IRS issues determination letters, rulings, opinion letters, and technical memoranda. These all are subject to I.R.C. $\$ 6110$, which generally opens these materials and supporting documents to the public. It makes exceptions for information that would identify particular taxpayers, or for other privileged and confidential information of a commercial or financial nature. The SEC issues no-action letters, interpretative releases, and reports of investigations. 
ernment should protect such competitively sensitive information from disclosure by reporting only on generic categories of efficiencies. The government should indicate in which categories significant efficiencies were found-such as in research and development, in the rationalization of manufacturing facilities, or in the elimination of duplicate operations. The report also should indicate market power, the magnitudes of the efficiencies, what percentage or dollar amount of expected cost savings was deemed sufficient to offset the risk of increased market power, the industries involved, and the merging firms' relative position within the industry. ${ }^{64}$

Finally, section $18 \mathrm{a}(\mathrm{h})$ of the HSR Act might itself be considered an obstacle to a Merger Guidelines reporting requirement. Under the Freedom of Information Act, ${ }^{65}$ information provided by the merging parties is exempt from disclosure. The HSR Act also prohibits the DOJ and FTC from publicly disclosing such information, except in connection with an administrative or court proceeding or for the benefit of Congress. Plainly, Congress intended to protect confidential information from disclosure. ${ }^{66}$ However, neither the congressional debates nor legislative history indicate that Congress intended to prevent the government from publicly reporting meaningful information concerning its own merger enforcement policies and practices.

The reporting requirement that I have proposed need not disclose confidential information. Furthermore, much of the in-

64 From a public-policy point of view, whether to disclose or to protect firm-specific efficiency claims may present a close question. Because the claimed efficiencies are offset against inferences of market power based on market structure, it is arguable that the merging firms should be required to waive any claims of confidentiality concerning the information disclosed. An apt analogy may be the injured plaintiff who puts his injury at issue in litigation by seeking to recover damages. In such an instance, the doctor-patient privilege regarding medical examinations related to the injury is waived. However, because no legislation creates such a waiver in merger cases, a reporting requirement should protect confidentiality of business information.

655 U.S.C. $\S 552$ (1982).

66 See, e.g., 122 Cong. REc. 30,827, 30,877 (1976). 
formation reported by the merging parties, as well as supplemental information generated by the government's own investigation, is already in the public domain. However, the government should ensure that confidential information will be protected, and should allay concerns that merging parties might have regarding a government report on merger enforcement policies and practices. To this end, the government should consider issuing a formal interpretation of the HSR Act and its rules ${ }^{67}$ that describes in detail the nature and content of the annual informational report. As additional protection, the government might create a procedure that would give parties who respond to second requests an opportunity to review and object to information contained in the government's annual report before its release to Congress. ${ }^{68}$

However, the literal language of the HSR Act might be interpreted as prohibiting even the informational reporting proposed here. If so, serious consideration should be given to amending the HSR Act so that the benefits of a reporting requirement could be realized. In the interim, government enforcement agencies should consider an alternative strategy for providing additional information concerning the Merger Guidelines. Such a strategy could involve issuing interpretive regulations or rulings similar in format to those employed by the IRS. Alternatively, formal or informal reports could be issued. While I prefer a more detailed reporting requirement, the important point is to create an effective vehicle for providing the public with a greater flow of information concerning merger enforcement.

67 See 16 C.F.R. $\$ 803.30$, which authorizes the FTC, with the concurrence of the assistant attorney general for antitrust, to issue formal interpretations of the rules and the HSR Act.

68 A similar procedure is available for parties who have been required to produce documents in response to a civil investigative demand and then learn that the government intends to disclose the discovered information to third parties while taking oral testimony as part of an antitrust investigation. The objecting party may petition a federal district court for a protective order. See Aluminum Co. v. United States, 444 F. Supp. 1342 (D.D.C. 1978). 


\section{Conclusion}

Increasingly sophisticated merger analysis, together with vast government discretion and an avowed "fix-it-first" approach toward mergers, presents a real problem. This may indeed be the best way to handle mergers, but, at present, there is an unacceptable loss in predictability and a potential for abuse of the country's merger laws. The remedy I have suggested here-an information-reporting requirement-is quite modest. Yet I believe it can be quite effective, if the government enforcement agencies embrace the opportunity to increase the flow of information to the public concerning merger enforcement. It is in the government's best interest, as well as the public's, to do so soon. 